\title{
Korelasi Genotipe dan Fenotipe Antar Sifat Kuantitatif Pada Populasi Segregasi Transgresif Kacang Hijau
}

\section{Genotype and Phenotype Correlation Between the Quantitative Traits in Transgressive Segregation Population of Mungbean}

\author{
Julian Timisela ${ }^{1}$, Aca A. Anakotta ${ }^{2}$, Adriana Hiariej ${ }^{1}$, Edizon Jambormias, ${ }^{2, *}$ \\ ${ }^{1}$ Jurusan Biologi Fakultas MIPA Universitas Pattimura Ambon, Jl. Ir. M. Putuhena, Kampus Poka Ambon 97233 \\ Indonesia \\ ${ }^{2}$ Departemen Pemuliaan Tanaman Fakultas Pertanian Universitas Pattimura, Jl. Ir. M. Putuhena, Kampus Poka Ambon \\ 97233 Indonesia \\ "E-mail Penulis Korespondensi: edizon.jambormias@ faperta.unpatti.ac.id \\ Tanggal submisi: 06 Agustus 2019; Tanggal penerimaan: 3 Februari 2020
}

\begin{abstract}
Mung bean (Vigna radiata L. Wilczek) is one of the food plants as a source of vegetable protein for humans. One of these is a population of transgressive segregation resulting from crossing in mung beans. This research aims to estimate the correlation between genotype and phenotype values between quantitative traits in the transgressive segregation population of mung beans. Genetic material was 11 lines of transgressive segregated in the selection generation S2:2 of varieties Mamasa Lere Butnem $\times$ Lasafu Lere Butnem crosses. Genotype correlation analysis was obtained from the decomposition of genetic variance components from the results of the analysis of variance according to a randomized complete design with sub-sampling, consisting of 13 genotypes (including check varieties) which were two replications. The results showed a genotype correlation between the quantitative traits of mung beans that indicated the possibility of direct selection of the populations of transgressive segregation lines on yields and indirectly through easily observable traits such as harvest age, number of pods, and number of seeds.
\end{abstract}

Keywords: genetic correlation, mungbeans, quantitative traits

\section{ABSTRAK}

Kacang hijau (Vigna radiata L. Wilczek) merupakan salah satu tanaman pangan sebagai sumber protein nabati bagi manusia. Salah satu diantaranya adalah populasi segregasi transgresif hasil persilangan pada kacang hijau. Penelitian ini bertujuan untuk menduga nilai korelasi genotipe dan fenotipe antar sifat-sifat kuantitatif pada populasi segregasi transgresif kacang hijau. Bahan genetik adalah 11 galur segregan transgresif pada generasi seleksi S2:2 zuriat persilangan varietas Mamasa Lere Butnem $\times$ Lasafu Lere Butnem. Analisis korelasi genotipe diperoleh dari penguraian komponen ragam-peragam genetik dari hasil analisis peragam sesuai model acak rancangan acak lengkap dengan anak contoh, terdiri atas 13 genotipe (termasuk varietas penguji) yang diulang dua kali. Hasil penelitian memperlihatkan adanya korelasi genotipe antar sifat-sifat kuantitatif kacang hijau yang mengindikasikan kemungkinan seleksi langsung populasi galur segregasi transgresif terhadap hasil maupun tak-langsung melalui sifat yang mudah diamati seperti umur panen, jumlah polong dan jumlah biji.

Kata Kunci: kacang hijau, korelasi genetik, sifat kuantitatif

\section{PENDAHULUAN}

Kacang hijau (Vigna radiata L. Wilczek) merupakan salah satu tanaman pangan sebagai sumber protein nabati bagi manusia. Tanaman ini dapat tumbuh di segala macam tipe tanah yang berdrainase baik dan dapat ditanam di dataran rendah hingga ketinggian 500 meter di atas permukaan laut. Untuk dapat tumbuh dan berkembang dengan baik, kacang hijau menghendaki curah hujan optimal antara 50-200 mm/bulan, dengan suhu $25-27^{\circ} \mathrm{C}$, kelembaban udara $50-80 \%$ dan cukup mendapat sinar matahari (Humaedah, 2014). Pengembangan varietas baru kacang hijau bertujuan untuk meningkatkan daya hasil di atas 2 ton/ha dan dapat dipanen serempak pada selang umur panen 60 hari (Chadha, 2010). Perbaikan produktivitas dan panen 
serempak dilakukan oleh Jambormias et al. (2015) melalui seleksi segregasi transgresif sifat berganda dan menghasilkan beberapa galur segregasi transgresif, diantaranya dari zuriat persilangan varietas Mamasa Lere Butnem $\times$ Lasafu Lere Butnem. Galur-galur ini dihasilkan melalui pelaksanaan seleksi pada Generasi F2 dalam dua tahap seleksi generasi awal (Generasi Seleksi S2:2) untuk memperoleh galur harapan berdaya hasil tinggi dan panen serentak.

Varietas Mamasa Lere Butnem dan Lasafu Lere Butnem merupakan varietas lokal kacang hijau di Maluku yang telah lama dibudidayakan petani di Pulau Jamdena Kabupaten Kepulauan Tanimbar. Varietasvarietas ini memiliki keunggulan dapat tumbuh pada kondisi sangat basah (Hetharie et al., 2002), varietas lokal Lasafu Lere Butnem mepunyai produksi tinggi tetapi berumur dalam yaitu \pm 90 hari, sedangkan galur Mamasa Lere Butnem berumur genjah yaitu \pm 60 hari (Jambormias et al., 2013a) dan memiliki daya gabung umum tinggi untuk indeks panen serempak (Jambormias et al., 2011).

Bila seleksi hasil biji masih diperlukan pada generasi berikutnya, dan bila telah terjadi penyempitan keragaman genetik hasil biji karena seleksi pada generasi awal, maka seleksi tak langsung melalui indikator seleksi cenderung dapat meningkatkan hasil biji (Oz et al., 2009; Jambormias et al., 2013b). Hasil biji merupakan sifat bernilai ekonomis yang disebut karakter seleksi, sedangkan sifat-sifat yang diseleksi disebut indikator seleksi (Jambormias et al., 2013b). Indikator seleksi selain dapat digunakan untuk melakukan seleksi tak langsung terhadap karakter seleksi, juga digunakan untuk menyusun indeks seleksi dalam seleksi langsung banyak sifat secara serempak (Wirnas et al., 2006; Jambormias et al., 2011) dan seleksi untuk mendapatkan "tipe tanaman ideal" (Sumarno dan Zuraida, 2006).

Penelitian ini bertujuan untuk menduga nilai korelasi genotipe dan fenotipe antar sifat-sifat kuantitatif kacang hijau pada Generasi Seleksi S2:2 zuriat persilangan varietas Mamasa Lere Butnem $\times$ Lasafu Lere Butnem.

\section{Metode Penelitian}

Bahan penelitian ini adalah 11 galur segregasi transgresif pada Generasi Seleksi S2:2 dari zuriat persilangan varietas lokal Lasafu Lere Butnem $\times$ Mamasa Lere Butnem dan dua varietas unggul nasional sebagai penmbanding yaitu Vima-1 dan Kutilang.

\section{Rancangan Percobaan}

Rancangan yang digunakan dalam penelitian ini adalah rancangan acak lengkap dengan anak contoh, terdiri atas 13 genotipe (galur $13+2$ varietas unggul) dan diulang 2 kali.Pada setiap genotipe diamati 6 tanaman sebagai contoh acak. Dengan demikian terdapat 34 satuan percobaan dan 204 satuan pengamatan. Model linear umum percobaan ini adalah:

$$
y_{i j k}=\mu+\tau_{i}+\varepsilon_{i j}+\delta_{i j k}
$$

untuk: $i=1,2, \ldots, 13$ genotipe, $j=1,2$ ulangan; dan $k=$ $1,2, \ldots, 6$ contoh acak.

dimana: $y_{i j k}=$ pengamatan genotipe baru individu ke- $k$ pada family ke- $i$ dan blok ke- $j ; \mu=$ nilai tengah umum; $\tau_{i}=$ pengaruh adit dari kelompok ke- $I ; \varepsilon_{i j}=$ pengaruh acak dari perlakuan ke- $i$ dan kelompok; $\delta_{i j k}=$ pengaruh acak dari perlakuan ke- $k$ yang tersarang dalam gugus famili ke- $i$.

Model analisis ragam dan peragam bagi model linear umum ini diasumsikan merupakan model acak (random model), yaitu untuk menduga komponen ragam genotipe dan fenotipe.

\section{Pelaksanaan Penelitian}

Lahan dibersihkan dari gulma-gulma dan dibiarkan selama 2-3 hari, diolah dan dibuat petak-petak percobaan sebanyak satuan percobaan. Penanaman dilakukan secara tugal dengan jarak tanaman $30 \mathrm{~cm}$ antar barisan dan $20 \mathrm{~cm}$ dalam barisan. Pemeliharaan tanaman meliputi pemupukan, penyiraman jika tidak hujan, pengendalian gulma, hama dan penyakit. Sebelum penanaman diberikan pupuk kandang per petak percobaan.

Pengamatan dilakukan terhadap seluruh tanaman pada setiap petak percobaan. Sifat-sifat tanaman yang diamati adalah: tinggi tanaman, jumalah cabang, jumlah polong, lama hari panen, umur panen terakhir, jumlah biji, jumlah biji bernas, jumlah biji per polong, jumlah polong bernas, bobot biji, berat 100 biji, dan persen biji bernas.

\section{Analisis Data}

Analisis data dalam penelitian ini meliputi analisis ragam serta analisis korelasi genotipe dan fenotipe. Hasil analisis ragam digunakan untuk melakukan pengujian hipotesis mengenai pengaruh genotipe dari masing-masing sifat yang diamati dengan menggunakan Uji $F$. Sifat-sifat yang menunjukkan pengaruh nyata (Nilai peluang $<0,05$ ) kemudian dianalisis korelasi genotipe dan fenotipe antar sifat kuantitatif.

\section{HASIL DAN PEMBAHASAN}

\section{Pengaruh Genotipe Terhadap Sifat-Sifat Kuantitatif Kacang Hijau}

Hasil analisis ragam menunjukkan bahwa faktor famili atau genotipe memberikan pengaruh yang sangat nyata terhadap hampir semua sifat kuantitatif (Tabel 1). Pengaruh sangat nyata terjadi pada sifat-sifat kuantitatif dengan Nilai $P<0,01$, kecuali jumlah daun yang memberikan pengaruh nyata $(0,01 \leq$ nilai $P<0,05)$. Hasil ini menunjukkan adanya keragaman genetik yang tinggi di antara galur-galur segregan transgresif. 
Tabel 1. Hasil uji statistik sifat-sifat kuantitatif galur-galur segregan transgresif kacang hijau zuriat persilangan varietas Mamasa Lere Butnem $\times$ Lasafu Lere Butnem

\begin{tabular}{lccc}
\hline \multirow{2}{*}{ Sifat kuantitatif } & \multicolumn{2}{c}{ Nilai Peluang Statistik Uji F } \\
\cline { 2 - 4 } & Blok & Famili & Sampel(famili) \\
\hline Tinggi tanaman & 0,003 & 0,000 & 0,997 \\
Jumlah cabang & 0,328 & 0,001 & 0,963 \\
Jumlah daun & 0,397 & 0,010 & 0,318 \\
Umur panen terakhir & 0,000 & 0,000 & 1,000 \\
Lama hari panen & 0,000 & 0,000 & 1,000 \\
Jumlah polong & 0,000 & 0,000 & 0,742 \\
Jumlah polong bernas & 0,000 & 0,000 & 0,781 \\
Jumlah biji & 0,255 & 0,000 & 0,995 \\
Jumlah biji bernas & 0,703 & 0,000 & 0,991 \\
Jumlah biji per polong & 0,000 & 0,002 & 0,466 \\
Bobot biji & 0,000 & 0,000 & 0,994 \\
B100 & 0,000 & 0,000 & 1,000 \\
Persen biji bernas & 0,129 & 0,000 & 0,994 \\
\hline
\end{tabular}

Keragaman genetik suatu sifat yang tinggi mengindikasikan adanya galur-galur dengan penampilan yang berbeda, dan perbedaan ini dapat tejadi karena faktor genetik. Ragam genetik menjadi besar apabila galur berkerabat jauh, mendekati homozigot, dan berasal dari persilangan induk-induk yang berbeda latar belakang genetik (Trustinah et al., 2013), walaupun memiliki fenotipe yang mirip asalkan dapat menghasilkan segregan transgresif (Jambormias et al., 2014). Hasil penelitian ini memperlihatkan bahwa masih terdapat keragaman antar famili-famili zuriat persilangan tetapi tidak ada keragaman dalam famili.

Keragaman antar famili yang tinggi memperlihatkan bahwa terdapat keragaman genetik antar famili-famili segregan transgresif, sehingga masih terdapat kemungkinan dilakukan seleksi lebih lanjut untuk mendapatkan galur segregan transgresif berdaya hasil tinggi. Sebaliknya, ragam sampel dalam famili yang rendah mengindikasikan bahwa seleksi yang dilakukan sebelumnya pada generasi awal sudah dapat memfiksasi segregan transgresif (Jambormias et al., 2014). Adanya keragaman antar famili yang tinggi masih terdapat pada sifat-sifat tinggi tanaman, jumlah cabang, jumlah daun, umur panen terakhir, lama hari panen, jumlah polong, jumlah polong bernas, jumlah biji, jumlah biji bernas, jumlah biji per polong, bobot biji, berat 100 biji, dan persen biji bernas menunjukkan bahwa masih terdapat peluang untuk melakukan seleksi. Seleksi berdasarkan sifat-sifat ini masih memungkinkan untuk dapat diperolehnya galur-galur segregan transgresif yang masih lebih baik, khususnya untuk sifat-sifat yang menjadi tujuan seleksi seperti untuk sifat umur panen terakhir, bobot biji, jumlah polong (Singh et al., 2015).

\section{Korelasi Genetik Antar Sifat-Sifat Kuantitatif Kacang Hijau}

Analisis korelasi genetik meliputi dua komponen utama dalam suatu populasi pemuliaan (breeding population) yaitu korelasi fenotipe dan genotipe antar sifat kuantitatif. Analisis ini memainkan peranan penting dalam seleksi, khususnya untuk menentukan indikator seleksi suatu sifat bernilai ekonomis penting dalam seleksi tak langsung. Korelasi fenotipe mencakup inferensia mengenai kejadian korelasi secara fenotipe atau yang dapat dideteksi oleh pancaindera manusia. Sebaliknya korelasi genotipe bertalian dengan inferensia korelasi oleh karena aksi gen belaka tanpa adanya pengaruh lingkungan, sehingga tidak dapat terdeteksi oleh pancaindera manusia, tetapi dapat diprediksi secara empiris (Nzuve et al., 2014). Hasil analisis korelasi fenotipe menunjukkan bahwa terdapat hubungan yang nyata, sangat nyata maupun tidak nyata antara sifat-sifat kuantitatif tanaman (Tabel 2). Sifat penting yaitu bobot biji memperlihatkan korelasi fenotipe positif sangat nyata dengan sifat jumlah polong dan jumlah polong bernas, masing-masing dengan nilai koefisien korelasi fenotipe yang sama yaitu 0,75 . Hasil yang sama juga di peroleh Hakim (2006) yang memperlihatkan adanya korelasi fenotipe positif dengan kedua sifat ini yaitu 0,75 .

Korelasi fenotipe positif nyata juga terlihat antara bobot biji dengan sifat-sifat umur panen terakhir, lama hari panen, jumlah biji dan jumlah biji bernas. Besarnya koefisien korelasi fenotipe ini masing-masing 0,53, 0,62, 0,61 dan 0,67 . Selain korelasi positif, terdapat satu sifat kuantitatif yang memperlihatkan korelasi fenotipe negatif nyata, yaitu jumlah biji per polong, dengan koefisien korelasi fenotipe sebesar -0,60. Hasil ini sama dengan Zubair (2004) yang memperlihatkan adanya korelasi fenotipe negatif antara kedua karakter ini, yaitu -0,50. Selain korelasi negatif dengan jumlah biji per polong, bobot biji juga tidak mempunyai korelasi fenotipe dengan tinggi tanaman, jumlah cabang dan jumlah daun.

Sifat bernilai ekonomis berikutnya pada kacang hijau, yaitu umur genjah dengan indikatornya adalah umur panen terakhir, juga memperlihatkan hubungan secara fenotipe dengan sifat-sifat kuantitatif lainnya. Sifat umur panen terakhir, selain mempunyai korelasi fenotipe positif nyata dengan bobot biji, juga 
memperlihatkan korelasi fenotipe nyata hingga sangat nyata dengan sifat-sifat tinggi tana man, jumlah cabang, lama hari panen, jumlah polong, jumlah polong bernas, jumlah biji, jumlah biji bernasdan persentase biji bernas. Besarnya koefisien korelasi fenotipe ini masing-masing $0,66,0,55,0,95,0,81,0,80,0,74,0,75$ dan 0,52. Sama seperti sifat bobot biji, umur panen terakhir juga mempunyai korelasi fenotipe negatif dengan jumlah biji per tanaman, dengan koefisien korelasi -0,58. Sifat ini hanya tidak memperlihatkan korelasi yang nyata dengan jumlah daun dan bobot 100 biji.

Hasil analisis korelasi genetik lainnya yang laten adalah korelasi genotipe. Hasil analisis korelasi ini menunjukkan adanya korelasi genotipe positif sangat nyata, nyata dan tidak nyata antara sifat-sifat kuantitatif tanaman, sama seperti analisis korelasi fenotipe (Tabel 2). Terlihat pula bahwa sifat bobot biji memperlihatkan korelasi genotipe positif sangat nyata dengan sifat jumlah cabang, umur panen terakhir, jumlah polong dan jumlah polong bernas, jumlah biji, jumlah biji bernas masingmasing dengan nilai $0,69,0,95,0,77,0,76,0,72$ dan 0,73 . Korelasi genotipe positif nyata juga terlihat antara bobot biji dengan sifat persen biji bernas. Besarnya koefisien korelasi genotipe ini masing-masing 0,62 dan 0,52. Hasil yang sama juga diperoleh Kumar et al. (2010) yang memperlihatkan adanya korelasi genotipe yang sama antara kedua sifat ini. Hanya dengan tinggi tanaman, jumlah cabang dan jumlah daun, sifat bobot biji tidak menunjukkan korelasi genotipe yang nyata. Sama seperti pada analisis korelasi fenotipe, sifat bernilai ekonomis umur panen terakhir, selain mempunyai korelasi genotipe positif nyata dengan bobot biji, juga memperlihatkan korelasi genotipe nyata hingga sangat nyata dengan sifatsifat tinggi tanaman, jumlah cabang,lama hari panen, jumlah polong, jumlah polong bernas, jumlah biji, jumlah biji bernas, bobot biji dan persentase biji bernas. Besarnya koefisien korelasi genotipe ini masing-masing $0,66,0,57,0,95,0,82,0,81,0,74,0,76,0,54$ dan 0,54 Sama seperti sifat bobot biji, umur panen juga mempunyai korelasi genotipe negatif dengan jumlah biji per tanaman, dengan nilai koefisien korelasi adalah 0,59. Sifat ini hanya tidak memperlihatkan korelasi yang nyata dengan jumlah daun dan bobot 100 biji. Hasil yang sama juga diperlihatkan oleh Trustinah et al. (2014) yang juga memperlihatkan adanya korelasi negatif antara umur panen dengan kedua sifat ini.

Sifat lama hari panen yang merupakan indikator panen serempak lainnya mempunyai korelasi genotipe positif sangat nyata dan nyata dengan tinggi tanaman, jumlah cabang, umur panen terakhir, jumlah polong, jumlah polong bernas, jumlah biji, jumlah biji bernas, bobot biji dan persen biji bernas. Besarnya koefisien korelasi genotipe ini masing-masing 0,58, 0,71, 0,95, $0,78,0,77,0,73,0,74,0,63$, dan 0,53 . Sifat ini tidak mempunyai korelasi dengan sifat jumlah daun dan bobot 100 biji.
Analisis korelasi genetik memainkan peranan yang cukup penting dalam analisis genetik. Analisis ini meliputi dua analisis penting, yaitu korelasi fenotipe dan genotipe antar sifat-sifat kuantitatif. Korelasi genotipe bertalian dengan kecenderungan laten perilaku keterpautan antar gen-gen kuantitatif suatu sifat dengan gen-gen kuantitatif sifat yang lain pada satu atau beberapa kromosom yang sama. Korelasi genotipe positif mengindikasikan kemungkinan keterpautan antar gengen dari kedua sifat adalah sis (coupling), dan sebaliknya korelasi negatif mengindikasikan kemungkinan keterpautan trans (repulsion). Korelasi yang sangat tinggi malah dapat mengindikasikan keterpautan pada suatu kromsom, atau bahkan mengindikasikan kemungkinan pleiotropiknya kedua sifat yang berkorelasi. Sebaliknya korelasi fenotipe bertalian dengan kecenderungan hubungan secara morfologis antar sifat-sifat yang berkorelasi (Sumarno dan Zuraida, 2006).

Analisis korelasi fenotipe dan genotipe juga memainkan peranan yang penting dalam program pemuliaan tanaman khususnya program seleksi. Seleksi terhadap suatu sifat cenderung menyebabkan terjadinya perubahan terhadap sifat lainnya. Sifat penting yang menjadi tujuan dalam seleksi umumnya bernilai ekonomis. Sebaliknya sifat yang tidak penting, yang bukan menjadi tujuan seleksi, dapat bernilai penting apabila berkorelasi dengan sifat penting. Sifat-sifat ini dapat dipertimbangkan indikator seleksi dalam seleksi tak langsung terhadap sifat yang menjadi tujuan seleksi. Demikian pula seleksi langsung terhadap sifat penting yang menjadi tujuan seleksi dengan sendirinya menghasilkan pengaruh ikutan dalam bentuk perubahan fenotipe sifat-sifat lainnya yang mempunyai korelasi genotipe dengan sifat penting itu (Wirnas et al., 2006).

Pada kacang hijau, sifat penting bernilai ekonomis adalah bobot biji. Sifat ini merupakan ukuran kuantitatif bagian tanaman yang digunakan manusia sebagai bahan pangan. Selain itu, sifat-sifat penting lainnya adalah panen serempak dan umur genjah. Kedua sifat ini berkaitan erat dengan curahan waktu dan tenaga kerja dalam kegiatan usaha tani. Pada penelitian ini, ketiga sifat ini selain masih memperlihatkan keragaman antar famili, juga masih menunjukkan kecenderungan korelasi fenotipe dan genotipe dengan beberapa sifat kuantitatif maupun yang tidak berkorelasi. Di antara ketiga sifat penting ini, terdapat korelasi fenotipe dan genotipe yang positif satu sama lainnya. Dalam hal ini, korelasi genotipe antar ketiga sifat mengindikasikan bahwa gengen aditif ketiga sifat ini cenderung terpaut secara sis atau bahkan mungkin pleiotropik positif dalam satu atau beberapa kromosom yang sama. Oleh sebab itu, dalam hubungannya dengan seleksi, ketiga sifat ini, selain merupakan sifat yang menjadi tujuan seleksi, juga dapat dijadikan sebagai indikator seleksi satu terhadap yang lainnya (Bizeti et al., 2004). 
Tabel 2. Korelasi fenotipe antar sifat kuantitatif pada galur-galur segregan transgresif kacang hijau zuriat persilangan Mamasa Lere Butnem $\times$ Lasafu Lere Butnem

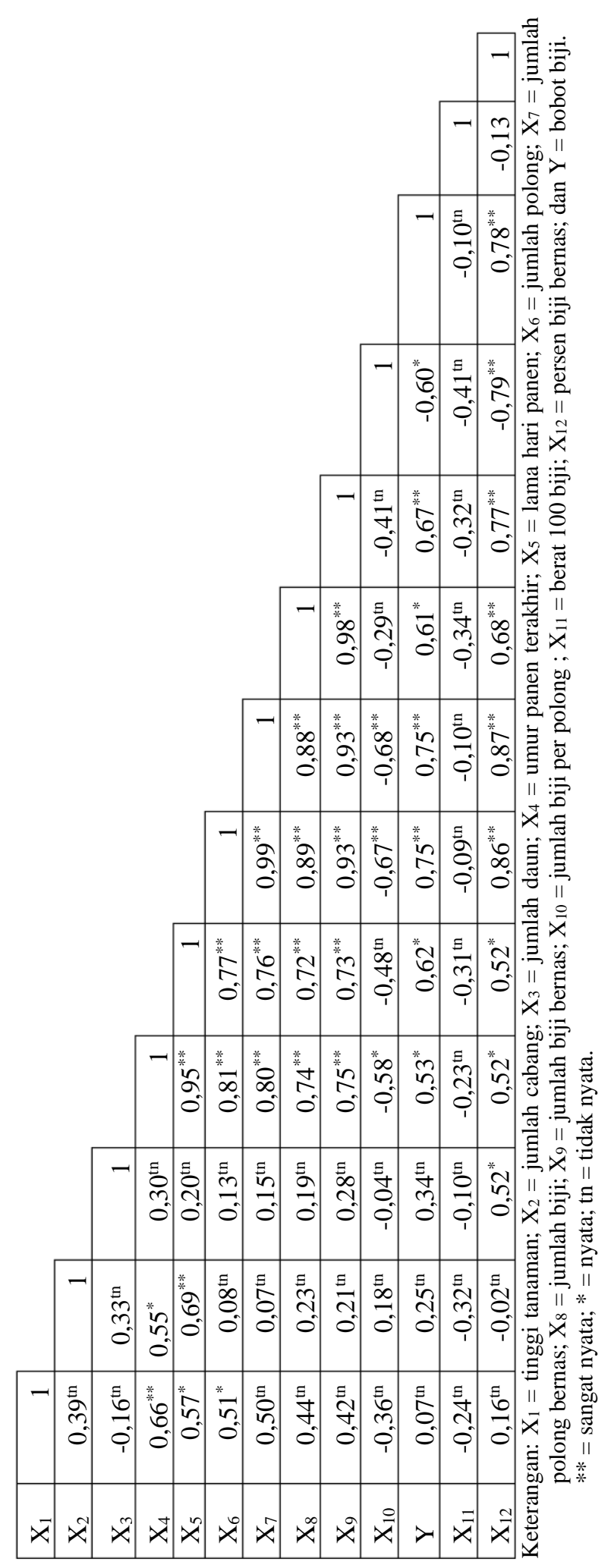


Tabel 3. Korelasi genotipe antar sifat kuantitatif pada galur-galur segregan transgresif kacang hijau zuriat persilangan Mamasa Lere Butnem $\times$ Lasafu Lere Butnem

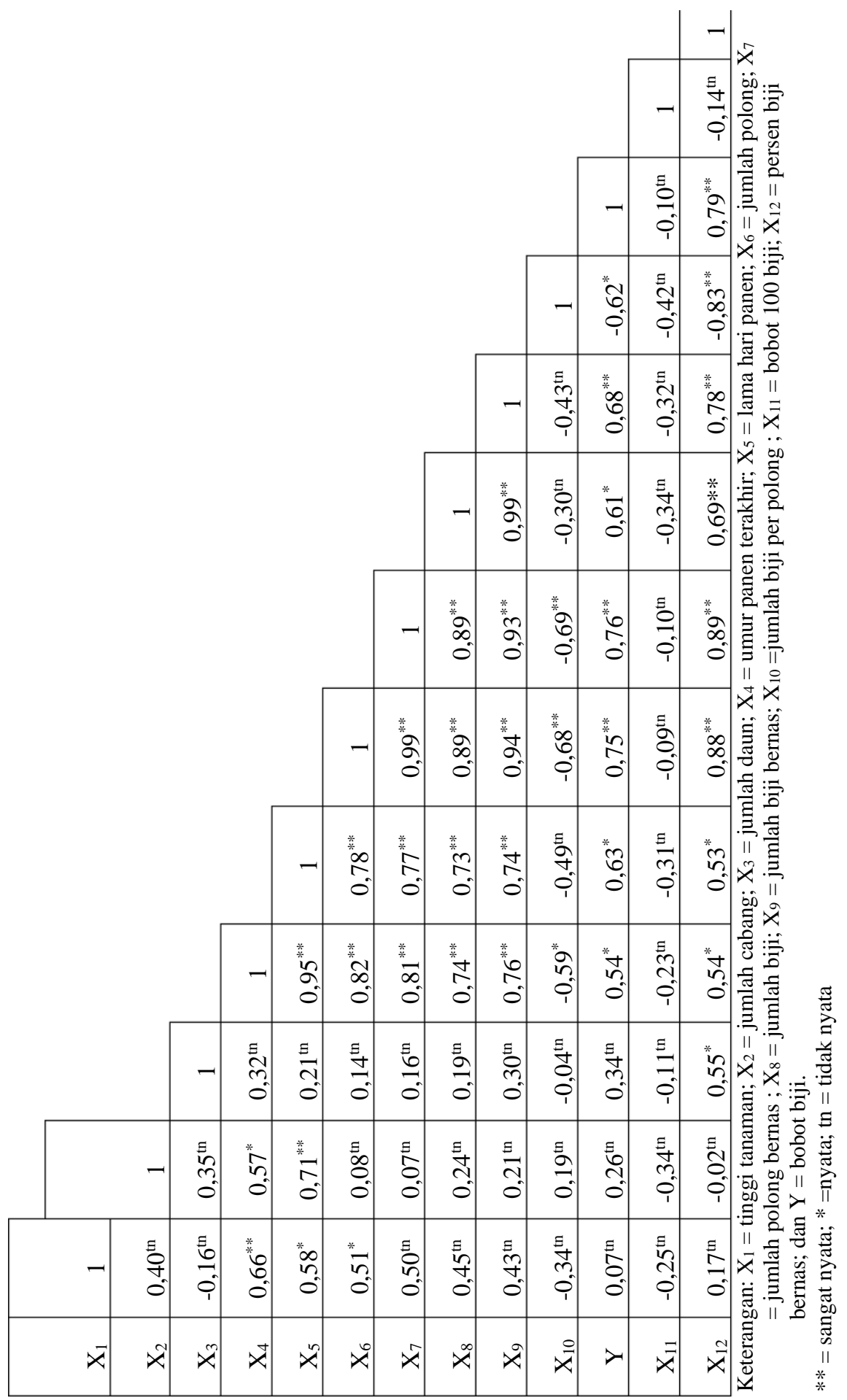

Hasil penelitian memperlihatkan umur berbunga tidak memperlihatkan keragaman genetik sehingga tidak dapat dipertimbangkan sebagai indikator seleksi terhadap ketiga sifat penting. Di lain pihak, umur panen terakhir dapat teramati lebih awal dibandingkan dengan pengamatan bobot biji, sehingga dapat dipertimbangkan sebagai indikator seleksi karena mempunyai korelasi fenotipe dan genotipe dengan bobot biji dan lama hari panen (Sudarmadji et al., 2007).

Sifat kuantitatif yang teramati lebih awal berikutnya adalah jumlah cabang. Sifat ini hanya mempunyai korelasi fenotipe dan genotipe positif dengan umur panen terakhir dan lama hari panen, tetapi tidak dengan bobot biji. Oleh sebab itu, terdapat kemungkinan 
adanya pautan secara sis atau pleiotropik antara sifat jumlah cabang dengan umur panen dan lama hari panen, tetapi berpeluang untuk berada pada kromosom yang berbeda dengan bobot biji. Sifat jumlah cabang ini dapat dipertimbangkan pula sebagai indikator seleksi untuk kedua sifat penting bobot biji dan keserempakan panen (Jambormias, 2009).

Sifat kuantitatif yang mudah teramati lebih awal lainnya adalah jumlah polong. Sifat ini selain mempunyai korelasi fenotipe dan genotipe positif dengan bobot biji, juga dengan sifat-sifat lainnya yang samasama merupakan komponen produksi seperti jumlah polong bernas, jumlah biji dan jumlah biji bernas. Oleh sebab itu, jumlah polong dapat pula dipertimbangkan pula sebagai indikator seleksi bobot biji.

Sifat berikutnya yang mudah teramati lebih awal lainnya adalah jumlah biji. Sifat ini mempunyai korelasi fenotipe dan genotipe positif dengan semua sifat penting yaitu bobot biji, lama hari panen dan umur panen terakhir. Dalam hal ini, komponen produksi ini dapat dianggap berpaut secara sis dalam satu atau beberapa kromosom atau pleiotropik dengan ketiga sifat penting. Oleh sebab itu, sifat ini juga dapat dipertimbangkan sebagai indikator seleksi bagi ketiga sifat penting ini (Srihartati et al., 2009).

Sifat terakhir yang mudah teramati lebih awal adalah sifat jumlah biji per polong. Sifat ini mempunyai korelasi fenotipe dan genotipe negatif dengan umur panen terakhir, lama hari panen, bobot biji dan hampir semua komponen produksi lainnya. Sifat ini dapat bersifat pleitropik negatif atau terpaut secara trans pada satu atau beberapa kromosom dengan sifat-sifat yang berkorelasi negatif ini. Oleh sebab itu, sifat ini juga dapat dipertimbangkan sebagai indikator seleksi (Sujiprihati et al., 2012).

Sifat-sifat kuantitatif lainnya seperti jumlah polong bernas, jumlah biji bernas, bobot 100 biji dan persentase biji bernas merupakan sifat-sifat komponen hasil yang penting untuk mendukung produksi, tetapi nilainya baru diketahui setelah panen, sehingga tidak dapat dipertimbangkan sebagai indikator seleksi (Jambormias, 2014).

\section{Kesearahan Korelasi Fenotipe dan Genotipe}

Kegiatan utama dalam suatu program pemuliaan tanaman adalah seleksi. Seleksi dilakukan terhadap nilai fenotipe, tetapi yang berubah adalah nilai genotipe. Oleh sebab itu, dalam seleksi tak langsung, dimana seleksi yang dilakukan terhadap suatu sifat non ekonomis menyebabkan perbaikan pada sifat ekonomis, memerlukan sinkronisasi antara korelasi fenotipe dengan korelasi genotipe. Agar sinkron, maka sebaiknya terdapat kesearahan antara korelasi fenotipe dengan korelasi genotipe dari sifat yang diseleksi tak langsung dengan sifat penting yang menjadi tujuan seleksi tetapi baru terdeteksi pasca pemanenan.

Terdapat dua bentuk kesearahan hubungan antara sifat-sifat kuantitatif, yaitu korelasi searah dan tidak searah. Dua koefisien korelasi fenotipe dan genotipe disebut searah ketika keduanya memiliki koefisien korelasi bertanda sama, yaitu positif vs positif atau negatif vs negatif (Jambormias et al., 2003). Sebaliknya, bila salah satu negatif dan yang lainnya positif atau tidak nyata, maka kedua koefisien korelasi itu tidak searah.

Kompilasi nilai koefisien korelasi fenotipe (Tabel 2) dan nilai koefisien korelasi genotipe (Tabel 3) menghasilkan tabulasi kesearahan nilai koefisien korelasi fenotipe dengan koefisien korelasi genotipe (Tabel 4). Hasil kompilasi ini menunjukkan bahwa terdapat kesearahan antara koefisien korelasi fenotipe dan genotipe pada semua sifat kuantitatif kacang hijau.

Korelasi genotipe antar sifat, yaitu nilai korelasi yang bersifat laten, cenderung menunjukkan nilai yang sama, atau cenderung searah dengan koefisien korelasi fenotipe, sehingga menghasilkan inferensia yang sama seperti korelasi fenotipe (Wijayati, 2014). Hasil penelitian memperlihatkan bahwa terdapat kesearahan nilai korelasi fenotipe dengan korelasi genotipe untuk semua sifat-sifat kuantitatif, termasuk sifat penting bernilai ekonomis seperti bobot biji, umur panen terakhir dan lama hari panen, maupun sifat yang dijadikan sebagai indikator seleksi seperti jumlah cabang dan jumlah biji (Susanto dan Adie, 2006).

Nilai korelasi fenotipe yang searah dengan korelasi genotipe sangat bermanfaat dalam pelaksanaan seleksi, baik seleksi langsung maupun seleksi tak langsung. Korelasi fenotipe yang searah dengan korelasi genotipe mengindikasikan bahwa seleksi berdasarkan nilai fenotipe untuk memilih galur baru juga terwariskan pada generasi berikutnya karena nilai genotipe yang terpilih. Oleh sebab itu, seleksi langsung berdasarkan nilai fenotipe untuk memilih galur-galur berdasarkan salah satu dari ketiga sifat ini, juga dapat memberikan perubahan secara genotipe pada kedua sifat lainnya, maupun sifat-sifat tak penting yang lain.

Diantara ketiga sifat bernilai ekonomis, umur panen terakhir merupakan sifat yang teramati lebih awal. Kepentingan ekonomis dari sifat ini adalah dapat diperolehnya galur baru berumur genjah melalui seleksi negatif. Adanya korelasi fenotipe dan genotipe yang positif mengindikasikan bahwa seleksi terhadap tanaman berumur genjah bersifat negatif untuk bobot biji, tetapi positif untuk lama hari panen (Saeed et al., 2007).

Pada keadaan ini, perolehan galur baru berumur genjah cenderung pula meningkatkan keserempakan panen, tetapi dapat menurunkan produksi biji. Namun demikian, seleksi untuk memperoleh galur berumur genjah, juga memungkinkan diperolehnya tanaman yang kerdil dan mempunyai jumlah biji per polong banyak, tetapi memiliki jumlah cabang, jumlah polong, jumlah polong bernas, jumlah biji dan jumlah biji bernasyang sedikit. Oleh sebab itu, seleksi untuk memperoleh galur berumur genjah lebih banyak menghasilkan kerugian. Keadaan yang sama seperti umur genjah, juga berlaku apabila seleksi bertujuan untuk meningkatkan kecenderungan panen serempak (Hary et al., 2013). 
Tabel 4. Kesearahan korelasi positif fenotipe dan genotipe nyata pada sifat- sifat kuantitaif tanaman kacang hijau

\begin{tabular}{|c|c|c|c|}
\hline $\begin{array}{l}\text { Sifat-sifat } \\
\text { Berkorelasi }\end{array}$ & Nilai korelasi Fenotipe & Nilai korelasi Genotipe & Kesearahan \\
\hline $\mathrm{X}_{4}-\mathrm{X}_{1}$ & $0,66^{* *}$ & $0,66^{* *}$ & Searah \\
\hline $\mathrm{X}_{5}-\mathrm{X}_{2}$ & $0,69^{* *}$ & $0,71^{* *}$ & Searah \\
\hline $\mathrm{X}_{5}-\mathrm{X}_{4}$ & $0,95^{\text {** }}$ & $0,95^{* *}$ & Searah \\
\hline $\mathrm{X}_{6}-\mathrm{X}_{4}$ & $0,81^{* *}$ & $0,82^{* *}$ & Searah \\
\hline $\mathrm{X}_{6}-\mathrm{X}_{5}$ & $0,77^{* *}$ & $0,78^{* *}$ & Searah \\
\hline $\mathrm{x}_{7}-\mathrm{X}_{4}$ & $0,80^{* *}$ & $0,81^{* *}$ & Searah \\
\hline $\mathrm{X}_{7}-\mathrm{X}_{5}$ & $0,76^{* *}$ & $0,77^{* *}$ & Searah \\
\hline $\mathrm{x}_{7}-\mathrm{X}_{6}$ & $0,99^{* *}$ & $0,99^{* *}$ & Searah \\
\hline $\mathrm{X}_{8}-\mathrm{X}_{4}$ & $0,74^{* *}$ & $0,74^{* *}$ & Searah \\
\hline $\mathrm{X}_{8}-\mathrm{X}_{5}$ & $0,72^{* *}$ & $0,73^{* *}$ & Searah \\
\hline $\mathrm{X}_{8}-\mathrm{X}_{6}$ & $0,89^{* *}$ & $0,89^{* *}$ & Searah \\
\hline $\mathrm{X}_{8}-\mathrm{X}_{7}$ & $0,88^{* *}$ & $0,89^{* *}$ & Searah \\
\hline $\mathrm{X}_{9}-\mathrm{X}_{4}$ & $0,75^{\text {** }}$ & $0,76^{* *}$ & Searah \\
\hline $\mathrm{X}_{9}-\mathrm{X}_{5}$ & $0,73^{* *}$ & $0,74^{* *}$ & Searah \\
\hline $\mathrm{X}_{9}-\mathrm{X}_{6}$ & $0,93^{* *}$ & $0,94^{* *}$ & Searah \\
\hline $\mathrm{X}_{9}-\mathrm{X}_{7}$ & $0,93^{* *}$ & $0,93^{* *}$ & Searah \\
\hline $\mathrm{X}_{9}-\mathrm{X}_{8}$ & $0,98^{* *}$ & $0,99^{* *}$ & Searah \\
\hline$y-x_{6}$ & $0,75^{* *}$ & $0,75^{\text {** }}$ & Searah \\
\hline$y-x_{7}$ & $0,75^{* *}$ & $0,76^{* *}$ & Searah \\
\hline$y-x_{8}$ & $0,61^{*}$ & $0,61^{*}$ & Searah \\
\hline$y-x_{9}$ & $0,67^{* *}$ & $0,68^{* *}$ & Searah \\
\hline $\mathrm{x}_{12}-\mathrm{x}_{6}$ & $0,86^{* *}$ & $0,88^{* *}$ & Searah \\
\hline $\mathrm{x}_{12}-\mathrm{X}_{7}$ & $0,87^{* *}$ & $0,89^{* *}$ & Searah \\
\hline $\mathrm{X}_{12}-\mathrm{X}_{8}$ & $0,68^{* *}$ & $0,69^{* *}$ & Searah \\
\hline $\mathrm{X}_{12}-\mathrm{X}_{9}$ & $0,77^{* *}$ & $0,78^{* *}$ & Searah \\
\hline $\mathrm{X}_{12}-\mathrm{X}_{11}$ & $0,78^{* *}$ & $0,79^{* *}$ & Searah \\
\hline $\mathrm{X}_{4}-\mathrm{X}_{2}$ & $0,55^{*}$ & $0,57^{*}$ & Searah \\
\hline $\mathrm{X}_{5}-\mathrm{X}_{1}$ & $0,57^{*}$ & $0,58^{*}$ & Searah \\
\hline $\mathrm{X} 6-\mathrm{X}_{1}$ & $0,51^{*}$ & $0,51^{*}$ & Searah \\
\hline $\mathrm{y}-\mathrm{x}_{4}$ & $0,53^{*}$ & $0,54^{*}$ & Searah \\
\hline$y-x_{5}$ & $0,62^{*}$ & $0,63^{*}$ & Searah \\
\hline $\mathrm{y}-\mathrm{x}_{8}$ & $0,61^{*}$ & $0,61^{*}$ & Searah \\
\hline $\mathrm{X}_{12}-\mathrm{X}_{3}$ & $0,52^{*}$ & $0,55^{*}$ & Searah \\
\hline $\mathrm{X}_{12}-\mathrm{X}_{4}$ & $0,52^{*}$ & $0,54^{*}$ & Searah \\
\hline $\mathrm{X}_{12}-\mathrm{X}_{5}$ & $0,52^{*}$ & $0,53^{*}$ & Searah \\
\hline $\mathrm{X}_{10}-\mathrm{X}_{4}$ & $-0,58^{*}$ & $-0,59^{*}$ & Searah \\
\hline $\mathrm{X}_{10}-\mathrm{X}_{6}$ & $-0,67^{* *}$ & $-0,68^{* *}$ & Searah \\
\hline $\mathrm{X}_{10}-\mathrm{X}_{7}$ & $-0,68^{* * *}$ & $-0,69^{* *}$ & Searah \\
\hline $\mathrm{y}-\mathrm{x}_{10}$ & $-0,60^{*}$ & $-0,60^{*}$ & Searah \\
\hline
\end{tabular}

Keterangan :X1 = tinggi tanaman; X2 = jumlah cabang; X3 = jumlah daun; X4 = umur panen terakhir; X5 = lama hari panen; X6 = jumlah polong $\mathrm{X} 7=$ jumlah polong bernas $; \mathrm{X} 8=$ jumlah biji; $\mathrm{X} 9=$ jumlah biji bernas; $\mathrm{X} 10=$ jumlah biji per polong ; $\mathrm{X} 11=$ berat 100 biji; $\mathrm{X} 12=$ persen biji bernas; dan $\mathrm{Y}=$ bobot biji.

Sifat kuantitatif yang teramati lebih awal berikutnya adalah jumlah cabang. Sifat ini hanya mempunyai korelasi positif dengan umur panen terakhir dan lama hari panen, tetapi tidak dengan bobot biji. Dalam hal ini, seleksi terhadap sifat ini hanya bermanfaat untuk mendapatkan galur harapan berumur genjah dan panen serempak, tanpa memberikan perubahan terhadap bobot biji yang merupakan sifat penting. Oleh sebab itu, sifat ini dapat digunakan sebagai indikator seleksi, dimana seleksi ditujukan untuk memperoleh galur harapan baru dengan sedikit jumlah cabang tetapi mempunyai bobot biji yang tinggi. Seleksi ini dengan sendirinya juga meningkatkan peluang diperolehnya galur berumur genjah dan panen serempak dengan menggunakan metode indeks seleksi (Jambormias dan Riry, 2009).

Sifat kuantitatif yang mudah terdeteksi lainnya adalah jumlah polong. Seleksi positif terhadap sifat ini dapat meningkatkan nilai sifat penting bobot biji dan sifat-sifat lainnya seperti jumlah polong, jumlah polong bernas, jumlah biji dan jumlah biji bernas, karena juga mempunyai korelasi fenotipe dan genotipe positif. Sebaliknya, karena juga terjadi korelasi fenotipe dan genotipe positif dengan tinggi tanaman, maka seleksi 
positif secara fenotipe terhadap jumlah polong, secara genotipe juga dapat menghasilkan galur harapan dengan postur tanaman yang tinggi. Namun demikian, karena mempunyai korelasi fenotipe dan genotipe yang positif dengan umur panen terakhir dan lama hari panen, maka galur yang dihasilkan bukan berumur genjah dan panen serempak. Oleh sebab itu, sifat ini tidak dapat dijadikan sebagai indikator seleksi (Kumar et al., 2014).

Kecenderungan yang sama dengan sifat jumlah polong adalah sifat jumlah biji, kecuali bahwa sifat ini tidak berkorelasi, baik fenotipe maupun genotipe dengan tinggi tanaman, sehingga berpeluang untuk dapat menghasilkan varietas kerdil berdaya hasil tinggi, walaupun gagal menghasilkan galur berumur genjah dan panen serempak. Oleh sebab itu, sifat ini juga dapat dipertimbangkan sebagai indikator seleksi (Aryana, 2009).

Sifat terakhir yang mudah teramati lebih awal adalah sifat jumlah biji per polong. Sifat ini mempunyai korelasi fenotipe dan genotipe negatif dengan umur panen terakhir dan lama hari panen sehingga menjadi indikator seleksi yang baik untuk pembentukan galur harapan berumur genjah dan panen serempak. Namun demikian, sifat ini berkorelasi negatif, baik fenotipe maupun genotipe dengan bobot biji dan komponen hasil lainnya, sehingga dapat menurunkan produksi. Oleh sebab itu, sama seperti umur panen dan lama hari panen, sifat ini tidak dapat dijadikan sebagai indikator seleksi (Wirnas et al., 2006).

Apabila tujuan seleksi adalah untuk memperoleh varietas berdaya hasil tinggi, berumur genjah dan panen serempak, maka sifat-sifat yang tidak dapat dijadikan indikator seleksi bagi ketiga sifat ini masih dapat dipertimbangkan dalam seleksi, tetapi dengan menggunakan metode seleksi sifat berganda (Jambormias, 2014), yaitu metode indeks seleksi diikuti dengan metode seleksi ekstrim (Walsh, 2010). Pada metode seperti ini, seleksi dilakukan untuk memilih contoh terbaik dengan indeks seleksi, diikuti dengan seleksi ekstrim sesuai batas seleksi (truncated selection) berdasarkan kriteria seleksi dari ketiga sifat (Jambormias, 2014).

\section{KESIMPULAN}

1. Terdapat perbedaan yang sangat nyata antar genotipe untuk semua sifat kuantitatif yang mengindikasikan keragaman genetik yang tinggi pada setiap sifat-sifat kuantitatif itu.

2. Terdapat korelasi fenotipe dan genotipe antar sifatsifat kuantitatif kacang hijau, khususnya korelasi positif antara sifat bobot biji dengan sifat-sifat umur panen terakhir, lama hari panen, jumlah biji dan jumlah biji bernas; lama hari panen dengan tinggi tanaman, jumlah cabang, umur panen terakhir, jumlah polong, jumlah polong bernas, jumlah biji, jumlah biji bernas, bobot biji dan persen biji bernas; umur panen dengan tinggi tanaman, jumlah cabang, lama hari panen, jumlah polong, jumlah polong bernas, jumlah biji, jumlah biji bernas dan persentase biji bernas.

3. Korelasi fenotipe cenderung searah dengan korelasi genotipe untuk semua sifat kuantitatif, yaitu tinggi tanaman, jumlah cabang, umur panen terakhir, lama hari panen, jumlah polong, jumlah polong bernas, jumlah biji, jumlah biji bernas dan persentase biji bernas. Oleh sebab itu, seleksi terhadap fenotipe cenderung sama dengan genotipe yang bersifat laten.

\section{DAFTAR PUSTAKA}

Aryana, I.G.P.M. 2009. Korelasi fenotipik, genotipik dan sidik lintas serta implikasinya pada seleksi padi beras merah. Journal of Crop Agro 2: 1-7.

Bizeti, H.S., C.G.P. de Carvalho, J. Souza, J.R.P. desauza, D. Destro. 2004. Path analysis under multicollinearity in soybean. Brazilian Archive of Biology and Technology 47: 669-676.

Chadha, M.L. 2010. Short Duration Mungbean: A New Success in South Asia. Asia-Pacific Association of Agricultural Research Institutions. FAO Regional Office for Asia and the Pacific. Bangkok: APAARI.

Hakim, L. 2006. Pemanfaatan keragaman genetik plasma nutfah kacang hijau asal introduksi. Penelitian Pertanian Tanaman Pangan 25: 176-180.

Hary, P., E., Kuswanto, and N. Basuki. 2013. Path analysis of some leaf characters related to downy mildew resistance in maize. Agrivita 35: 167-173.

Hetharie, H., J.R. Patty, dan R.K. Pattikawa. 2002. Evaluasi beberapa varietas kacang hijau lokal Pulau Yamdena di desa Halong Baru Kecamatan Teluk Ambon Bagula Kota Ambon. Jurnal Pertanian Kepulauan 1: 21-26.

Humaedah, U. 2014. Syarat Tumbuh Dan Budidaya Kacang Hijau. Penyuluhan Departemen Pertanian. Jakarta.

Jambormias, E., E.L. Madubun, dan F.J.D. Hitijahubessy. 2003. Daya hasil, keragaman genetik alami dan heretabilitas sifat-sifat kuantitatif kacang hijau (Vigna radiata $L$. Wilczek) varietas lokal Jamdena. Jurnal Pertanian Kepulauan 2: 27-32.

Jambormias, E. dan J. Riry. 2009. Penyesuaian data dan penggunaan informasi kekerabatan untuk mendeteksi segregan transgresif sifat kuantitatif pada tanaman menyerbuk sendiri (suatu pendekatan dalam seleksi). Jurnal Budidaya Pertanian 5: 11-18.

Jambormias, E., S.H. Sutjahjo, M. Jusuf, Suharsono. 2011. Using information from relatives and path analysis to select for yield and seed size in soybean. SABRAO Journal Breeding and Genetics 43: 44-58.

Jambormias, E., J.M. Tutupary, dan J.R. Patty. 2013a. Analisis dialel sifat berganda pada kacang hijau (Vigna radiata L. Wilczek). Agrinimal 3: 23-29.

Jambormias, E., S.H. Sutjahjo, A.A. Mattjik, Y. Wahyu, dan D. Wirnas. 2013b. Indikator dan kriteria 
seleksi pada generasi awal untuk perbaikan hasil biji kacang hijau berumur genjah. Jurnal Agronomi Indonesia 41: 221-227.

Jambormias, E. 2014. Analisi Genetik dan Segregasi Transgesif berbasis kekerabatan untuk potensi hasil dan panen serempak kacang hijau. Bogor: Institut Pertanian Bogor. 150 hal.

Jambormias, E., S.H. Sutjahjo, A.A. Mattjik, Y. Wahyu, D. Wirnas, A. Siregar, J.R. Patty, J.K. Laisina, E.L. Madubun, and R.E. Ririhena. 2015. Transgressive segregation analysis of multiple traits in mungbean (Vigna radiata L. Wilczek). SABRAO Journal Breeding and Genetics 47: 201213.

Kang, M.S. 2002. Quantitative Genetics. Genomic and Plant Breeding. Florida. pp. 221-243.

Kumar, V.N, G.R. Lavanya, S.K. Singh, and P. Pandey. 2010. Genetic association and path coefficient analysis in mung bean Vigna radiata (L.) Wilczek. AAB Bioflux 2: 251-258.

Kumar, C.P., R. Rekha, O. Venkateswarulu, and R.P. Vasanthi. 2014. Correlation and path coefficient analysis in groundnut (Arachis hypogaea L.). International Journal of Applied Biology and Pharmaceutical Technology 5: 8-11.

Nzuve, F., S. Githiri, D.M. Mukunya, and J. Gethi. 2014. Genetic Variability and correlation studies of grain yield and related agronomic traits in Maize. Journal of Agricultural Science 6: 88-92.

Oz, M., A. Karasu, A.T. Goksoy, and Z.M. Turan. 2009. Interrelationship of agronomical characteristic in soybean (Glycine max) grown in different environments. International Journal of Agriculture and Biology 11: 85-88.
Saeed, I., G.S.S. Khattak, and R. Zamir. 2007. Association of seed yield and some important morphological traits in mungbean (Vigna radiata (L.) Wilczek). Pakistan Journal of Botany 39: 2361-2366.

Singh, C.M., A.K. Singh, S.B. Mishra, A. Pandey, and B. Kumar. 2015. Detection of epistasis for yield and some important agro-morphological traits in (Vigna radiata (L.) Wilczek). Legume Genomics \& Genetics 6: 1-7.

Srihartati, R.R., A. Setiawan, B. Heliyanto, D. Pranowo, dan Sudarsono. 2009. Keragaan morfologi dan hasil 60 individu jarak pagar (Jatropha curcas L.) terpilih di Kebun Percobaan Pakuwon Sukabumi. Jurnal Littri 15: 152-161.

Sujiprihati, S., M. Syukur, dan R. Yunianti. 2012. Teknik Pemuliaan Tanaman. Penebar Swadaya. Jakarta.

Sumarno, dan N. Zuraida. 2006. Hubungan korelatif dan kausatif antara komponen hasil dengan hasil kedelai. Jurnal Penelitian Pertanian Tanaman Pangan 25: 38-44.

Trustinah, R., B.S., Prasetiaswati, N. Harnowo, Didik. 2014. Adopsi Varietas unggul kacang hijau di sentra produksi. Iptek Tanaman Pangan 9: 24-38.

Wijayati, R.Y., P. Setyastuti, dan A. Muchlish. 2014. Hubungan hasil dan komponen hasil kedelai (Glycine max (L.) populasi F5. Jurnal Vegetalika 3: 88-97.

Wirnas, D., I. Widodo, Sobir, Trikoesoemaningtyas, dan D. Sopandie. 2006. Pemilihan karakter agronomi untuk menyusun indeks seleksi pada 11 populasi kedelai Generasi F6. Buletin Agronomi 34:19-24.

Zubair, M. 2004. Genetic diversity and gene action in mungbean. Pakistan Research Repository. University of Arid Agriculture, 1-8. Rawalpin. 